\title{
Skin Color in Apples-Influence of Copigmentation and Plastid Pigments on Shade and Darkness of Red Color in Five Genotypes
}

\author{
Jane E Lancaster,Jan E. Grant ${ }^{1}$, and Carolyn E. Lister ${ }^{1}$ \\ Plant Improvement Division, New Zealand Institute for Crop and Food Research, Private Bag 4704, \\ Christchurch, New Zealand \\ Michael C. Taylor ${ }^{2}$
Forensic Division, Institute of Environmental Health and Forensic Sciences, P.O. Box29181, Christchurch,
New Zealand \\ Additional index words. anthocyanins, carotenoids, chlorophyll, chromameter, flavonoids, Malus domestics, microspectro- \\ photometer
}

\begin{abstract}
The biochemical and cytological mechanisms responsible for the differences in red color quality of apples (Malus domestics Borkh.) were investigated. Copigmentation, the increase in absorbance maxima ( $\lambda$ max) from anthocyanin and flavonoid interactions, is known to be a mechanism for producing variation in shade of red in flowers. In intact apple skin cells, the mean $\lambda$ max was $550 \mathrm{~nm}$, with no significant difference between genotypes. Furthermore, the ratio of flavonols and proanthocyanidins to anthocyanins was similar for all genotypes. Therefore, copigmentation is not a mechanism producing different shades of red in apples. Darkness of red skin was positively related to the proportion of red cells in the skin and the size of the vacuoles containing anthocyanins. Measurements of plastid pigments, chlorophyll, and carotenoids, compared with $L^{*}, a^{*}, b^{*}$ measurements, indicated that the visual blending of plastid pigments and anthocyanins has an important influence on red coloration of apple skin.
\end{abstract}

Apple skin color is caused by the pigments chlorophyll and carotenoids located in plastids and the phenolic pigments (anthocyanin, flavonols, and proanthocyanidins) located in the vacuole. The flavonols and proanthocyanidins do not contribute significantly to overall coloration but may be important in enhancing anthocyanin coloration by copigmentation.

Color is traditionally measured by destructive techniques, such as isolation and quantitation of pigments, or by nondestructive measurements based on determination of the characteristics of light, transmitted or reflected, by the fruit. The relationships between pigment composition, color measurement, and perception of color by the eye are complex, and evidence is lacking on the extent to which differences in pigment composition are apparent to the eye as color differences (Knee, 1980). In apples, red coloration is commercially desirable. Variation exists in the shade of red and the pattern of reddening (e.g., solid block or striping). This variation depends on the genotype and on developmental and environmental factors (Lancaster, 1992; Saure, 1990).

In flowers, there has been extensive work on the relationship between petal color and the types of anthocyanin and copigmentation (Osawa, 1982). The anthocyanins pelargonidin, cyanidin, and delphinidin produce scarlet, crimson, and blue-mauve shades, respectively [absorbance maxima ( $\lambda$ max) of 520,535, and $546 \mathrm{~nm}$ in $0.01 \% \mathrm{HCl}$ in methanol]. At the $\mathrm{pH}$ of cell vacuoles, anthocyanins form chemical bonds either between themselves (intramolecular copigmentation and self association) or with other phenolic molecules (intermolecular copigmentation). The bonds stabilize the pigment and result in an increase in absorbance and a shift in $\lambda$ max to longer wavelengths (bathochromic shift). Thus,

Received for publication 1 Dec. 1992. Accepted for publication 25 Apr. 1993. We thank G. Coles for the image analysis measurements, A. white for apple genotypes, and J.R.L. Walker and P. Reay for helpful discussions, The cost of publishing this paper was defrayed in part by the payment of page charges. Under postal regulations, this paper therefore must he hereby marked advertisement solely to indicate this fact.

'Research scientist.

${ }^{2}$ Forensic scientist. copigmentation results in the "bluing" of red shades. The mechanism of copigmentation is detailed by Brouillard (1983), Brouillard et al. (1989), and Mazza and Brouillard (1990).

The contribution of copigmentation phenomena to fruit color is not well researched, although fruit have an abundance of flavonols and proanthocyanidins suitable for copigmentation (Macheix et al., 1990). In grapes (Vitis vinifera L.), flavonol levels are too low to act as copigments, although self-association may occur at very high anthocyanin levels (Moskowitz and Hrazdina, 1981). A case for copigmentation contributing to a difference in skin color has been postulated for Ilex crenata Thunb. and I. rotunda C.P. Thunb. ex A. Murray in Linnaeus berries, which contain flavonols, and those of I. sinensis (Lees.) S.Y. Hu, which do not. Z. sinensis berry cells have a $\lambda$ max $12 \mathrm{~nm}$ lower than those of 1 . crenata and $\mathrm{Z}$. rotunda (Ishikura, 1975).

Apple skin contains mainly cyanidin-3-galactoside (Sun and Francis, 1967) and high concentrations of flavonols (quercetin glycosides) and proanthocyanidins, such as catechin (MacRae et al., 1990; Oleszek et al., 1989; Prabha and Patwardhan, 1985). Skin colors ranging from pink-red to deep purple-red are also found in diverse genotypes. It seemed feasible that copigmentation was a factor in producing the different shades of red in apple skin. In the work reported herein, we determined the $\lambda$ max of cells from the skin of different colored apple genotypes and the molar ratio of flavonols and proanthocyanidins to anthocyanins. We also determined the proportion of red cells in the skin of each genotype. Our results suggest that copigmentation is not a factor in producing differing shades of red. The anthocyanin concentration in the skin and the blending of color from chlorophyll and carotenoid pigments are shown to be important in determining the final red color.

\section{Materials and Methods}

\section{Plant material}

Five apples genotypes were used, representing a wide color variation: 'Granny Smith' (green background with bronze-red in 
areas exposed to high light intensities), 'Oregon Red Delicious' (deep purple-red), 'Regal Gala' (orange-red), and the breeding lines 4926 and 3827 (both crimson red). The color in each of the genotypes was uniform, not striped. Apples were picked at maturity from research orchards at Hastings, Hawkes Bay, New Zealand, and stored at 4C. Five apples from each genotype were used and analyzed individually.

\section{Color measurements}

Zones on each fruit $(3 \times 3 \mathrm{~cm})$ representing a range of color shade and intensity were labeled with a felt pen so that color measurements were made on the same area of skin used for microscopy. Color measurements were made using the $8-\mathrm{mm}$ diameter head of a portable tristimulus color analyzer (Chromameter II; Minolta, Ramsey, N. J.) and expressed in Commission International d'Eclairage $\mathrm{L}^{*}, \mathrm{a}^{*}, \mathrm{~b}^{*}$ color-space coordinates. The meter was calibrated using the manufacturer's standard white tile.

\section{Skin sections}

Skin sections from the labeled areas were cut by hand radially and tangentially using a single-edge blade, mounted in water, and viewed immediately. Only the part of a section that was one cell thick (of cuticle and epidermis) was used for the spectrophotometry of anthocyanin-containing cells.

\section{Microspectrophotometer}

Absorbance spectra of individual epidermal cells from the labeled areas were measured with a single-beamed microspectrophotometer (Nanospec 10S; Nanometrics, Sunnyvale, Calif.). The 20 - $\mu$ m-diameter measuring aperture was centered over the vacuole of the cell to be measured. Light intensity measurements were ratioed against those obtained from a colorless reference cell. Cells of each genotype were scanned from 450 to $650 \mathrm{~nm}$ to determine $\lambda$ max. Using the same sections, 50 cells from each genotype were scanned at $\lambda$ max $550 \mathrm{~nm}$ to determine the mean and range of absorbance. Clear vacuoles were used as a reference as above. Photomicrographs of sections of apple skin were made.

\section{Image analysis}

Image analysis of $35-\mathrm{mm}$ transparencies at $\times 20$ and $\times 40$ magnification was carried out using version three of the Chromatic Color Image Analysis System (Leading Edge, Bedford Park, South Australia), a video camera (model TK870E RGB; JVC, Japan), and a $33 \mathrm{MHz} 80486$-based personal computer. The video camera had a 1/2" charge-coupled device, and a 25-mm lens and 5 -mm extension tube were used to obtain a video image in which the transparency image just filled the video frame.

Images obtained were subjected to averaging filtration using a $3 \times 3$ kernel to remove signal noise, and pixel discrimination was carried out for color values that corresponded to the color of vacuoles containing pigment. In some genotypes (e.g., 'Granny Smith') it was necessary to carry out several discrimination procedures. In this case, the overlays produced by each discrimination were mixed until an overlay congruent with all pigmented vacuoles was produced. This overlay was used to calculate the proportion of the frame area pigmented. A similar procedure was used to determine the proportion of the frame occupied by all vacuoles, and the proportion of pigmented to total vacuoles was calculated.

\section{Analysis of pigment composition}

Apple skin of desired color was cut from the fruit and the underlying cortical cells were scraped off. Skin was weighed and extracted for analysis of anthocyanins, flavonols, procyanidins, chlorophylls, and carotenoids.

Chlorophyll extraction and estimation. The methods used for determining chlorophyll and total carotenoid content were essentially the same as those used by Knee (1972). Apple peel (0.5 to 1.0 g) was ground to a fine powder using liquid $\mathrm{N}$ and extracted with $15 \mathrm{ml}$ of cold acetone. The residue was reextracted with 5-ml aliquots of $80 \%$ acetone until clear. The combined extracts were adjusted to $30 \mathrm{ml}$ with $80 \%$ acetone and centrifuged at $5000 \times \mathrm{g}$ for $10 \mathrm{~min}$. Absorbance was measured at 645,652, and $663 \mathrm{~nm}$ and a reading was also taken at $700 \mathrm{~nm}$ to correct for any turbidity. Chlorophyll content was calculated from the data using the equations of Maclachlan and Zalik (Holden, 1965).

Total carotenoid estimation. A 10-ml aliquot of the acetone extract from the above procedure was taken and $10 \mathrm{ml}$ of petroleum ether (40 to 60C) and $3 \mathrm{ml} \mathrm{50 \%} \mathrm{saturated} \mathrm{aqueous} \mathrm{ammonium}$ sulfate were added. The upper phase was washed twice with $3 \mathrm{ml}$ of ammonium sulfate, $1 \mathrm{ml}$ of $25 \%(\mathrm{w} / \mathrm{v})$ potassium hydroxide in methanol was added, and the mixture was stirred for $15 \mathrm{~min}$. The upper phase was washed with $5 \mathrm{ml}$ water until clear. The petroleum ether solution was then dried over sodium sulfate for $1 \mathrm{~h}$ before the absorbance was read at $446 \mathrm{~nm}$. A reading was also taken at 550 $\mathrm{nm}$ to correct for any turbidity (Goodwin, 1955). Total carotenoid content was calculated, assuming extinction of a $1 \%$ solution in a $1-\mathrm{cm}$ light path optical cell $\left(\mathrm{E}^{1 \%} \mathrm{~cm}\right)$ is 2500 .

Flavonol and anthocyanin extraction. Apple peel $(0.5$ to $1.0 \mathrm{~g})$ was ground to a fine powder using liquid $\mathrm{N}$ and extracted with 10 $\mathrm{ml} 15.0 \%(\mathrm{v} / \mathrm{v})$ acetic acid in methanol. The residue was reextracted at least twice to remove all of the pigments. The combined extracts were centrifuged at $5000 \times \mathrm{g}$ for $10 \mathrm{~min}$. The extract was rotaryevaporated to almost dryness at $40 \mathrm{C}$ and taken up in 0.5 to $1.0 \mathrm{ml}$ of $15 \%(\mathrm{v} / \mathrm{v})$ acetic acid in methanol. The extract was centrifuged at $10,000 \times \mathrm{g}$ for $5 \mathrm{~min}$ before being injected directly into the highperformance liquid chromatography (HPLC). A solvent delivery control system with an automatic sample injector and a variablewavelength ultraviolet detector (models 600, WISP 712, and 490; Waters, Milford, Mass.) were used to identify and quantify the flavonoids. The column was $220 \times 4.6 \mathrm{~mm}$ fitted with a $18 \times 3.5$ mm guard column (Aquapore RP-18; Applied Biosystems, Foster City, Calif.). Chromatographic traces were recorded using the Waters-Dynamic Solutions Maxima program. Samples (1 to $5 \mu \mathrm{l}$ ) were injected onto a $25 \mathrm{C}$ column. A flow rate of $1.0 \mathrm{ml} \cdot \mathrm{min}^{-1}$ and a linear 15 -min solvent gradient from $5 \%$ to $20 \%$ acetonitrile in $10 \%$ (by volume) acetic acid in water with a $15 \mathrm{~min}$ hold at the final concentration was used. Eluted components were monitored at 350 $\mathrm{nm}$ for flavonols and $530 \mathrm{~nm}$ for anthocyanins. The individual compounds were identified and quantified from weighed amounts of known standards.

Proanthocyanin quantification. The extraction method was the same as for the flavonols and anthocyanins but the solvent used was $100 \%$ methanol. The same HPLC system was used as for the flavonols and anthocyanins with the following differences. Solvents used were A) $10.0 \%$ (v/v) acetic acid in water and B) water. Samples of $10 \mu \mathrm{l}$ were injected onto the column, which was maintained at $70 \mathrm{C}$. The flow rate was $1.0 \mathrm{ml} \cdot \mathrm{min}^{-1}$ and a linear $47-$ min solvent gradient of $10 \%$ to $82 \% \mathrm{~A}$, followed by a linear 8 -min solvent gradient of $82 \%$ to $100 \% \mathrm{~A}$, and a final hold at $100 \%$ for $5 \mathrm{~min}$ was used. Eluted components were monitored at $280 \mathrm{~nm}$ for proanthocyanidins and $313 \mathrm{~nm}$ for phenolic acids.

\section{Results}

In vivo light absorbance measurements. Apple skin cells with absorbance of 0.09 to 1.07 (pale to dark red) were scanned, where 
possible, for each genotype. For the blushed 'Granny Smith' fruit, only cells from pale to medium red were available $(\mathrm{A}=0.22$ to 0.45$)$. The mean $\lambda$ max for 19 cells from five genotypes was $550+5.9 \mathrm{~nm}$ (Fig. 1). For each of the genotypes, there was a broad $\lambda$ max, particularly for 'Oregon Red Delicious' and 'Regal Gala', which had the darkest skin color. In the blushed 'Granny Smith' fruit, the $\lambda$ max range was 550 to $556 \mathrm{~nm}$, with an average $\lambda$ max of $553 \pm 0.0 \mathrm{~nm}$. There was no trend of increasing $\lambda$ max with darker red skin. 'Oregon Red Delicious' had a 2-nm lower average $\lambda$ max than 'Granny Smith'. A correlation of absorbance to mean $\lambda$ max was carried out for apple cells, and no relationship was found $\left(r^{2}=0.10\right)$.

Copigmentation. Quercetin glycosides and proanthocyanidins function strongly in copigmentation and, thus, bathochromic shifts in $\lambda$ max (Osawa, 1982). High concentrations of both of these classes of compounds were present in each of the genotypes (Table 1). Flavonols were generally $1 \times 10^{2} \mathrm{M}$ for each of the genotypes; proanthocyanidins ranged from $0.64 \times 10^{-2} \mathrm{M}$ for 3827 to $2.2 \times 10^{-2}$ M for 'Oregon Red Delicious'. Anthocyanins showed a wider range (7-fold), from $\approx 0.2 \times 10-2 \mathrm{M}$ for 4926 and 3827 to $1.5 \times 10$ ${ }^{2} \mathrm{M}$ for 'Oregon Red Delicious'. The blushed 'Granny Smith' fruit contained minimal amounts of anthocyanin. These values were used to calculate the ratio of flavonols and proanthocyanidins to anthocyanins: Higher ratios indicate a greater potential for copigmentation. The genotypes 4926 and 3827 had a ratio of $=10$, whereas the darker red 'Regal Gala' and 'Oregon Red Delicious' had ratios of $\approx 3$ and 2 , respectively. 'Granny Smith' by far had the highest ratio of 208 .

Anthocyanin distribution in skin. Thin tangential sections of apple skin showed a nonuniform distribution of anthocyanin among epidermal cells for all five genotypes when viewed at magnification $\times 400$ (Fig. 2). Very dark, red cells were adjacent to naturally pale cells. However, within a cell, the vacuole(s) appeared uniform in color.

Transmission at $550 \mathrm{~nm}$ was measured for 50 cells for each genotype and absorbance was calculated. A colorless cell in each section was used as a reference. A histogram of vacuole absorbances was plotted for each genotype (Fig. 3). All genotypes, in the region of apple skin examined, showed some cells without anthocyanins in their vacuoles, This pattern was greatest for 'Granny Smith' (25\% without anthocyanins). In the blushed area of 'Granny Smith' skin, the $\lambda$ max of cells was 0.45 (2\% of cells) and, in $84 \%$ of the cells, it was $<0.20$. 'Oregon Red Delicious' and 'Regal Gala' showed a wide range of absorbance, from 0.0 to 0.85 and 1.20 respectively. For 'Regal Gala', $78 \%$ of the cells was $>0.65$ absorbance and 44\% for 'Oregon Red Delicious'. The genotypes 3827 and 4926 had an absorbance distribution between those of 'Granny Smith' and 'Regal Gala' and 'Oregon Red Delicious', with 20\% and $4 \%$ of the cells, respectively, with absorbance $>0.65$. Correspondingly, skin color of genotypes 3827 and 4926 was lighter red than that of 'Regal Gala' and 'Oregon Red Delicious' but darker than that of 'Granny Smith'. Thus, increasing redness of skin could be accounted for by a higher proportion of dark red cells.

'Oregon Red Delicious' is much darker than 'Regal Gala', although 'Regal Gala' has the higher proportion of higher absorbance cells. A possible explanation for this discrepancy is that 'Oregon Red Delicious' has its anthocyanin in up to three layers of cells in the epidermis (Fig. 2), whereas, in 'Regal Gala', anthocyanin is limited to one layer, and occasionally two. Alternatively, the darker color could be accounted for by the higher absorbance at shorter wavelengths (Fig. 1) of pigments, either in the vacuole or in the cytoplasm behind the vacuole.

A striking feature of the epidermal sections is the differences in vacuolar size within the cells. Cell size is similar for all genotypes,

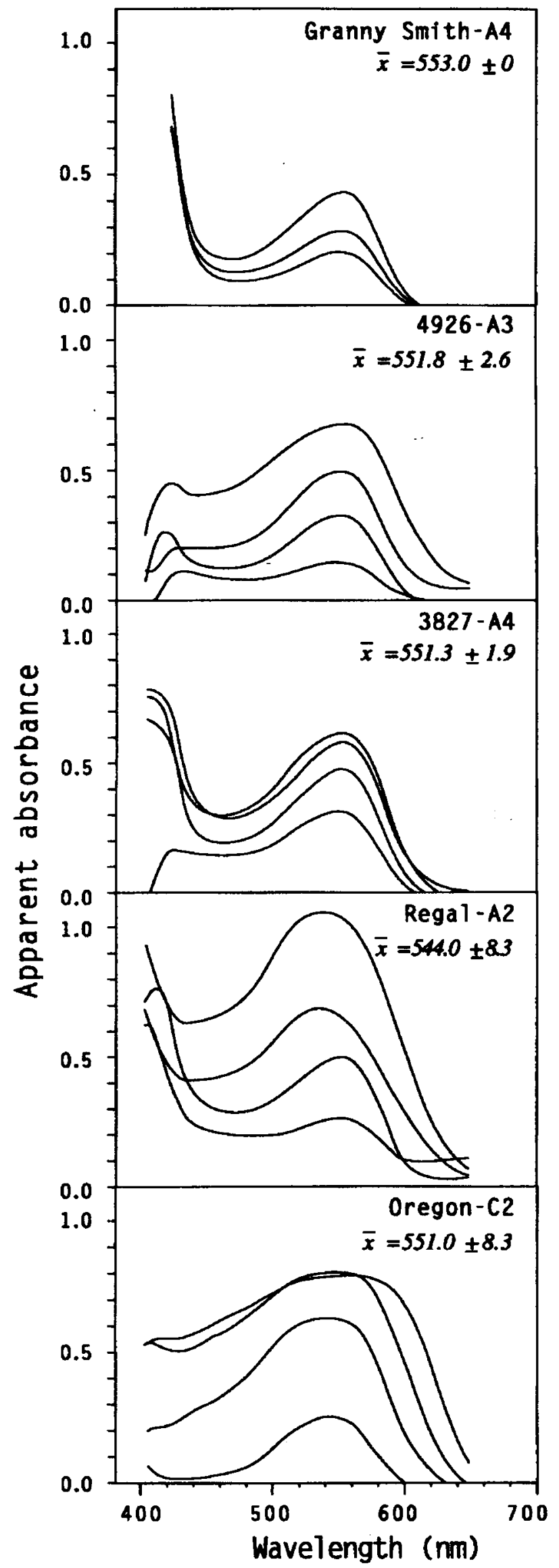

Fig. 1. Reflectance spectra (using a microspectrophotometer) of anthocyanincontaining vacuoles for five apple genotypes of specified skin areas. 
Table 1. Concentrations of anthocyanins, flavonols, and proanthocyanidins and the ratio of flavonols and proanthocyanidins and anthocyanins in relation to copigmentation potential of five apple genotypes.

\begin{tabular}{lccrr}
\hline \hline & $\begin{array}{c}\text { Anthocyanin } \\
(\mathrm{M})\end{array}$ & $\begin{array}{c}\text { Flavonol } \\
(\mathrm{M})\end{array}$ & $\begin{array}{c}\text { Proanthocyanidin } \\
(\mathrm{M})\end{array}$ & $\begin{array}{r}\text { Ratio } \\
(\mathrm{F}+\mathrm{P}) / \mathrm{A}\end{array}$ \\
Genotype & $0.09 \times 10^{-3}$ & $1.1 \times 10^{-2}$ & $0.78 \times 10^{-2}$ & 208 \\
Granny Smith & $0.27 \times 10^{-2}$ & $1.7 \times 10^{-2}$ & $0.86 \times 10^{-2}$ & 9.5 \\
4926 & $0.18 \times 10^{-2}$ & $1.3 \times 10^{-2}$ & $0.64 \times 10^{-2}$ & 10.7 \\
3827 & $0.66 \times 10^{-2}$ & $1.2 \times 10^{-2}$ & $1.1 \times 10^{-2}$ & 3.5 \\
Regal Gala & $1.50 \times 10^{-2}$ & $1.7 \times 10^{-2}$ & $2.2 \times 10^{-2}$ & 2.6 \\
Oregon Red Delicious & & & \\
\hline
\end{tabular}

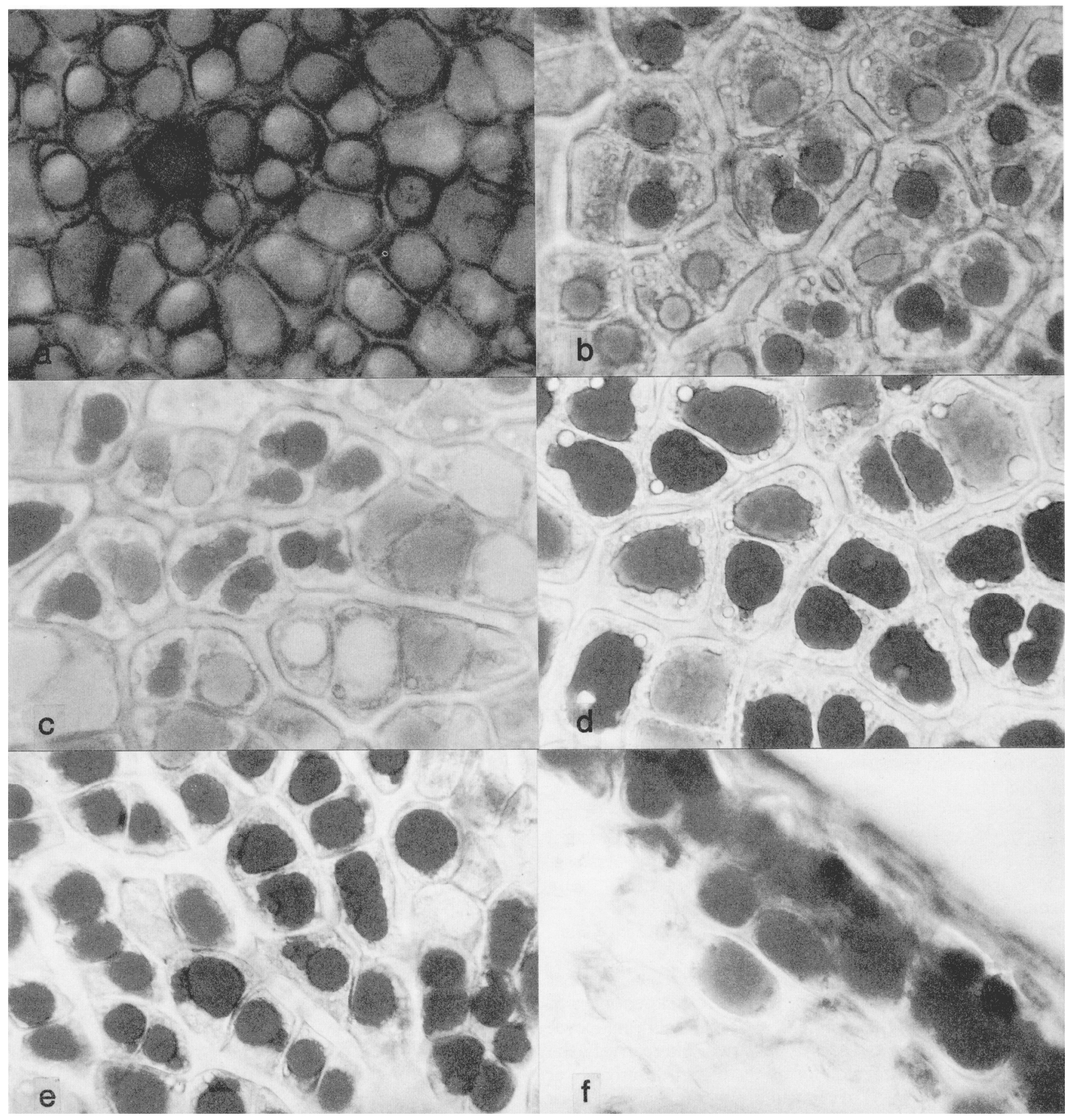

Fig. 2. Anthocyanin distribution in tangential (a-e) and transverse (f) sections of apple skin of (a) 'Granny Smith', (b) 3827, (c) 4926, (d) 'Regal Gala', and (e and f) 'Oregon Red Delicious'. Magnification ×236. 


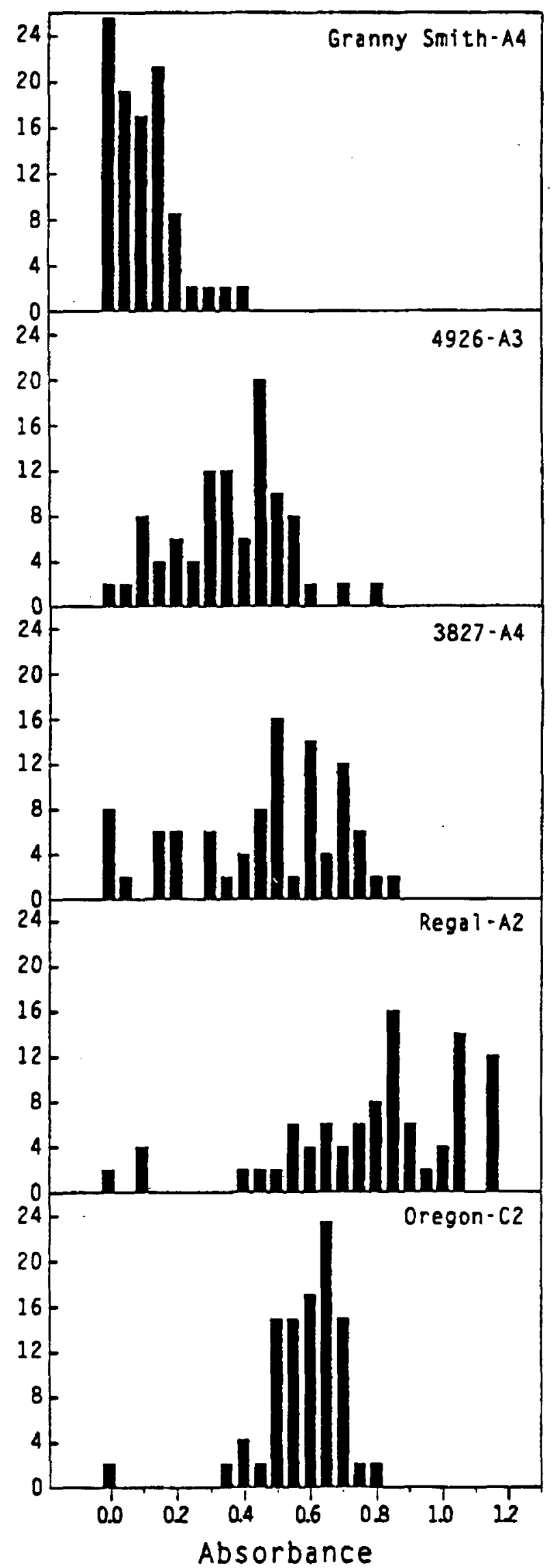

Fig. 3. Frequency (\%) of cells of varying redness ( $550 \mathrm{~nm}$ ) in tangential section of skin of specified areas of five apple genotypes. For 'Granny Smith', 50 cells were measured. For each of the other genotypes, 100 cells were measured. but there are up to 4 -fold differences in the area covered by vacuoles (Table 2). Vacuoles account for $\approx 50 \%$ of the surface area in 'Regal Gala', 'Oregon Red Delicious', and 'Granny Smith'; 3827 and 4926 have $\approx 20 \%$ and $30 \%$, respectively, of the cell area as vacuoles. Thus, 3827 and 4926 do not have the same potential for reddening as do the other three genotypes.

Influence of chlorophyll and carotenoids on redskin color. The microspectrophotometric studies on absorbance of individual cells have shown no major differences in $\lambda$ max; however, chromameter measurements on the skin of apple genotypes have shown large differences in $L^{*}, a^{*}, b^{*}$ values (Table 3), and differences in shade of red are apparent to the eye. Surprisingly, the darkest skinned genotype, 'Oregon Red Delicious', has a lower a* value than genotypes 3827 and 4926. The zones of apple skin used for microspectrophotometry were those typical of the mature fruit, and, in the case of 'Granny Smith', a blushed zone was used. There was no significant correlation between anthocyanin content and $a^{*}$ values, $\left(r^{2}=0.09\right)$, a result that is unexpected since $\mathrm{a}^{*}$ is a measure of redness. Neither $b^{*}$ or $\tan ^{1} b^{*} / a^{*}$ correlated with anthocyanin content. Lightness values $\left(\mathrm{L}^{*}\right)$ ranged from 47.6 for 'Granny Smith' to 33.9 for 'Oregon Red Delicious'. A coefficient of determination $\left(r^{2}=0.68\right)$ was obtained for the regression of anthocyanin content on $\mathrm{L}^{*}$ values. The five genotypes contain widely different levels of chlorophyll, carotenoids, and anthocyanins (Table 3). 'Granny Smith' is high in chlorophyll, whereas 'Regal Gala' contained no chlorophyll. Genotypes 3827, 4926, and 'Oregon Red Delicious' have levels of chlorophyll $\approx 25 \%$ that of 'Granny Smith'. Carotenoid levels were highest in 'Granny Smith', 'Regal Gala', and 4926 and lowest in 'Oregon Red Delicious'.

\section{Discussion}

Microspectrophotometer studies, although few in number, have shown bathochromic shifts in $\lambda$ max attributable to copigmentation. Petals of orange and red Azalea showed a 10-nm bathochromic shift attributable to the presence of flavonols in red Azalea (Asen et al., $197 \mathrm{lb}$ ). In Ilex berries, flavonols in I. crenata gave rise to putative copigmentation and an increased $\lambda$ max of $13 \mathrm{~nm}$ compared with the flavonol-free I. chinensis (Ishikura, 1975).

For the apple skin cells measured in this work, mean $\lambda$ max did not differ significantly among genotypes. There was no trend of increasing $\lambda$ max with darker red skin. Although the molarity of flavonols and proanthocyanidins in apple is in the range that one would consider to be effective in copigmentation in floral tissue (Asen et al., 1972; Chen and Hrazadina, 1981) and in vitro studies, there was little difference in copigmentation ratios between genotypes, and copigmentation ratios in the more deeply colored genotypes were lower than in the lightly colored genotypes. These results, together with the similarity of $\lambda$ max for the five genotypes, show that copigmentation is not an explanation for the different shades of red. Although a mean $\lambda$ max of $550 \mathrm{~nm}$ was observed for the apple cells, this was considerably higher than the 523-nm $\lambda$ max for cyanidin-3-galactoside in aqueous solution at $\mathrm{pH} 3.0$. This result suggests that copigmentation is a factor accounting for the higher $\lambda$ max in all of the genotypes, but it is not an explanation for genotype differences in shade of red.

The spectral absorbance of anthocyanins is also influenced by $\mathrm{pH}$. Between $\mathrm{pH} 3.5$ and 5.5, there is an equilibrium between the red flavylium cation and the blue-purple quinonoidal base. Increasing $\mathrm{pH}$ results in a shift to the quinonoidal base, a higher $\lambda$ max, and loss in absorbance (Macheix et al., 1990). The pH of apple epidermal tissue was determined as 3.6 to 4.0 (unpublished 
data), but there are no published measurements on $\mathrm{pH}$ of skin of different genotypes. The relative uniformity of $\lambda \max$ for the different genotypes argues against $\mathrm{pH}$ as an explanation for the different colors of red in different genotypes.

The darker colored 'Oregon Red Delicious' and 'Regal Gala' had a higher proportion of cells with higher absorbance at $550 \mathrm{~nm}$, larger vacuoles, and, in the case of the former genotype, up to three layers of red cells compared to only one in genotypes 4926 and 3826.

The apparently random distribution of colored cells in apple skin is a striking feature of this work. A similar distribution of red color in apple skin had been previously reported but not quantified by Dayton (1959), Dickinson and White (1986), and Misic and Tesovic (1971). Variation in the color of individual adjacent cells has also been observed in rose petals (Asen et al., 197 la), where the color difference was attributable to different vacuolar $\mathrm{pHs}$ of adjacent cells. The lack of discernible pattern in anthocyanin distribution in apple skin cells makes it difficult to suggest a cytological or developmental mechanism. Furthermore, for apple cells, light is one of the main determinants of anthocyanin production, yet adjacent cells would have the same light environment. The mechanism for producing the observed differences in cellular anthocyanin concentration remains unknown.

Although there were higher proportions of red cells in the skin of more darkly colored genotypes, such as 'Oregon Red Delicious', no correlation was observed between anthocyanin content and $\mathrm{a}^{*}$ values for the five genotypes. Singha et al. (1991) reported coefficients of determination for selected regression models relating chromaticity values to anthocyanin content. They found a poor correlation between $\mathrm{a}^{*}$ and anthocyanin levels $\left(R^{2}=0.10\right)$. Correlations between anthocyanin levels and chromaticity values $\left(\mathrm{a}^{*} /\right.$ $\left.\mathrm{b}^{*}\right)^{2}$ and $\mathrm{L}^{*}\left(\mathrm{a}^{*} \mathrm{~h} *\right)^{2}\left(R^{2}=0.81\right)$ were achieved with a separate equation for each strain of 'Delicious'. The relationships, however, are empirically derived and have no theoretical basis.

In some fruit \{e.g., tomato [Lycopersicon esculentum var. cerasiforme (Duval) A. Gray] and cranberry (Vaccinium macrocarpon Ait.) \}, there is good agreement among visual scores, red pigment content, and Hunter values (Francis and Clydesdale,

Table 2. Percentage of total skin area covered by vacuoles and percentage of anthocyanin-containing vacuoles in five apple genotypes differing in red skin color. Two photographic slides were measured for each genotype.

\begin{tabular}{lcc}
\hline \hline Genotype & $\begin{array}{c}\text { Total vacuole } \\
\text { area (\%) }\end{array}$ & $\begin{array}{c}\text { Anthocyanin- } \\
\text { containing } \\
\text { vacuoles (\%) }\end{array}$ \\
\hline 3827 & 20,13 & 100,92 \\
4926 & 36,27 & 97,96 \\
Granny Smith & 54,47 & 15,17 \\
Regal Gala & 41,49 & 97,100 \\
Oregon Red Delicious & 47,51 & 98,98 \\
\hline
\end{tabular}

1970; Larrigaudiere et al., 1991). For tomato, the a* value is sufficient to characterize maturity stages. However in each of these fruit, the pigment composition and pigment changes are simpler, whereas in apple skin, there are three pigment classes (chlorophyll, carotenoids, and anthocyanins).

For ripening peaches [Prunus persica (L.) Batsch.], major changes in color were reflected by an increase in $\mathrm{a}^{*}$ but no change in b* (Byrne et al., 1991; Delwiche and Baumgardner 1985). However, the increased $\mathrm{a}^{*}$ value was brought about by two pigment changes-a decrease in chlorophyll and an increase in anthocyanin. Similarly, for the surface of watermelons [Citrullus lanatus (Thunb. Matsum. \& Nakai)], an increase in a* values during ripening is brought about by a loss of chlorophyll. The carotenoid levels and, thus, the $\mathrm{b}^{*}$ value is constant, but the fruit appear more orange because the chlorophyll loss unmasks the carotenoids (Corey and Schlimme, 1988). In papaya (Carica papaya $\mathrm{L}$.), in which ripening is characterized by the fruit turning yellow and an increase in $b^{*}$ values, small green flecks considerably reduced the $a^{*}$ values (Peleg and Gomez Brito, 1975). Genotypes such as 'Oregon Red Delicious', which have high anthocyanin levels, and, therefore would be expected to have a higher $\mathrm{a}^{*}$ value, also have high chlorophyll levels, which reduce the $a^{*}$ value.

The modifying effect of chlorophyll on anthocyanins has also been monitored for eggplant (Solanum melongena L.), in which the darkest purple fruit had high levels of chlorophyll and anthocyanins (Nothmann et al., 1976). Likewise, in petals from tulip (Tulips gesnerana L.) and chrysanthemum [Dendranthema grandiflorum (Ramat.) Kitamura], carotenoids in the presence of anthocyanins modify the appearance to red-orange or bronze (Nieuwhof et al., 1989; Teynor et al., 1989). As Knee (1980) observed, evidence is lacking on the extent to which differences in pigment composition are apparent as color differences to the eye.

In conclusion, an increase in skin darkness in apples could be accounted for by increased anthocyanin concentration from a greater proportion of darker red vacuoles, larger vacuoles, and several layers of red cells. A change in the hue of the red coloration of apple skin from orange-red to bronze or purple-red is more likely to result from the visual blending of chlorophyll, carotenoids, and anthocyanins than from differences in copigmentation.

\section{Literature cited}

Asen, S., K.H. Norris, and R.N. Stewart. 1971a. Effect of pH and concentration of the anthocyanin-flavonol co-pigment complex on the color of 'Better Times' roses. J. Amer. Soc. Hort. Sci. 96:770-773.

Asen, S., R.N. Stewart, and K.H. Norris. 1971b. Co-pigmentation effect of quercetin glycosides on absorption characteristics of cyanidin glycosides and color of Red Wing Azalea. Photochemistry 10:17 1-175.

Asen, S., R.N. Stewart and K.H. Norris. 1972. Copigmentation of anthocyanins in plant tissues and its effect on colour. Phytochemistry 11:1139-1144.

Brouillard, R., G. Mazza, A.M. Albrecht-Gary, and A. Cheminat. 1989.

The copigmentation reaction of anthocyanins: A microprobe for the structural

Table 3. Chromaticity values $\left(\mathrm{L}^{*}, \mathrm{a}^{*}, \mathrm{~b}^{*}\right)$ and pigment content of apple skin of five genotypes differing in visual appearance.

\begin{tabular}{|c|c|c|c|c|c|c|}
\hline Genotype & $\mathrm{L}^{*}$ & $a^{*}$ & $b^{*}$ & $\begin{array}{l}\text { Chlorophyll } \\
\left(\mu \mathrm{g} \cdot \mathrm{g}^{-1} \text { fr } \mathrm{wt}\right)\end{array}$ & $\begin{array}{l}\text { Carotenoids } \\
\left(\mu \mathrm{g} \cdot \mathrm{g}^{-1} \mathrm{fr} \quad \mathrm{wt}\right)\end{array}$ & $\begin{array}{l}\text { Cyanidin-3- } \\
\text { galactoside } \\
\left(\mathrm{mg} \cdot \mathrm{g}^{-1} \mathrm{fr} \quad \mathrm{wt}\right)\end{array}$ \\
\hline Granny Smith & 47.6 & 3.5 & 16.2 & 170.8 & 21.7 & 0.025 \\
\hline 3827 & 39.5 & 20.2 & 6.8 & 37.7 & 10.4 & 0.5 \\
\hline 4926 & 45.4 & 30.8 & 14.8 & 61.3 & 15.5 & 0.8 \\
\hline Regal Gala & 35.8 & 9.2 & 1.6 & 0 & 16.3 & 1.9 \\
\hline Oregon Red Delicious & 33.9 & 7.1 & 0.8 & 40.7 & 8.6 & 4.1 \\
\hline
\end{tabular}


study of aqueous solutions. J. Amer. Chem. Soc. 111:2004-2610.

Brouillard, R. 1983. The in vivo expression of anthocyanin colour in plants. Photochemistry 22:1311-1323.

Byrne, D. H., A.N. Nikolic, and E.E. Bums. 1991. Variability in sugars, acids, firmness, and color characteristics of 12 peach genotypes. J. Amer. Soc. Hort. Sci. 116:1004-1006.

Chen, L.-J. and G. Hrazdina. 1981. Structural aspects of anthocyanin-flavonoid complex formation and its role in plant color. Phytochemistry 20:297-303.

Cory, K.A. and D.V. Schlimme. 1988. Relationship of rind gloss and groundspot color to flesh quality of watermelon fruits during maturation. Scientia Hort. 34:211-218.

Dayton, D.F. 1959. Red color distribution in apple skin. Proc. Amer. Soc. Hort Sci. 74:72-81.

Delwiche, M.J. and R.A. Baumgardner. 1985. Ground color measurements of peach. J. Amer. Soc. Hort. Sci. 108:1012-1016.

Dickinson, J.P. and A.G. White. 1986. Red colour distribution in the skin of Gala apple and some of its sports. N.Z.J. Agr. Res. 29:695-698.

Francis, F.J. and F.M. Clydesdale. 1970: Cranberry products. Food Prod. Dev. 4:54, 56, 60-62, 83,86.

Goodwin, T.W. 1955. Carotenoids, p. 272-3 11. In: K. Paech and M.V. Tracey (eds.). Modem methods in plant analyses. vol. 3. SpringerVerlag, Heidelberg.

Holden, M. 1965. Chlorophylls, p. 461488. In: T.W. Goodwin (cd.). Chemistry and biochemistry of plant pigments. Academic Press, London.

Ishikura, N. 1975. A further survey of anthocyanins and other phenolics in Ilex and Euonymus. Photochemistry 14;743-745.

Knee, M. 1972. Anthocyanin, carotenoid, and chlorophyll changes in the peel of Cox's Orange Pippin apples during ripening on and off the tree. J. Expt. Bot. 23:184-196.

Knee, M. 1980. Methods of measuring green color and chlorophyll content of apple fruit. J. Food Technol. 15:493-500.

Lancaster, J.E. 1992. Regulation of skin color in apples. Critical Rev. Plant Sci. 10:487-502.

Larrigaudière, C.A., Latchè, J.C. Peach, and C. Triantaphylides. 1991. Relationship between stress ethylene production induced by gamma irradiation and ripening of cherry tomatoes. J. Amer. Soc. Hort. Sci. 116:1000-1003.

Macheix, J.-J., A. Fleuriet, and J. Billet 1990. Fruit phenolics. Importance and roles of phenolic compounds in fruits. CRC Press, Boca Raton, Fla. p. 239-293.

Mazza, G. and R. Brouillard. 1990. The mechanism of co-pigmentation of anthocyanins in aqueous solutions. Photochemistry 29: 1097-1 102.

McRae, K.B., P.D. Lidster, A.C. De Marco, and A.J. Dick. 1990. Comparison of the polyphenol profiles of apple fruit cultivars by correspondence analysis. J. Sci. Food Agr. 50:329-342.

Misic, P.D. and Z.V. Tesovic. 1971. Anthocyanin color distribution in the skin of Cox's Orange Pippin apple and its dark-red sports. Hort. Res. 11:161-165.

Moskowitz, A.H. and G. Hrazdina. 1981. Vacuolar contents of fruit subepidermal cells from Vitis species. Plant Physiol. 68:686-692.

Nieuwhof, M., J.P. Van Eijk, and W. Eikelboom. 1989. Relation between flower color and pigment composition of tulip (Tulipa L.). Netherlands J. Agr. Sci. 37:365-370.

Nothmann, J., I. Rylski, and M. Spigelman. 1976. Color and variations in color intensity of fruit of egg-plant cultivars. Scientia Hort. 4: 191-197.

Oleszek, W., C.Y. Lee, A.W. Jaworski, and K.R. Price. 1989. Identification of some phenolic compounds in apples. J. Agr. Food Chem. 30:430-432.

Osawa, Y. 1982. Copigmentation of anthocyanins, p. 41-65. In: P. Markakis (cd.). Anthocyanins as food colors. Academic Press, New York.

Peleg, M. and L. Gómez Brito. 1975. The red component of the external color as a maturity index of Papaya fruits. J. Food Sci. 40: 1105-1106.

Prabha, T.N. and M.V. Patwardhan. 1985. A comparison of the polyphonic patterns in some Indian varieties of apples and their endogenous oxidation. I.J. Food Sci. Technol. 22:04-407.

Saure, M.C. 1990. External control of anthocyanin formation in apple. Scientia Hort. 42:181-218.

Singha, S., T.A. Baugher, E.C. Townsend, and M.C. D’Souza. 1991. Anthocyanin distribution in 'Delicious ' apples and the relationship between anthocyanin concentration and chromaticity values. J. Amer. Soc. Hort. Sci. 116:497-499.

Sun, B.H. and F.J. Francis. 1967. Apple anthocyanins: Identification of cyanidin 7-arabinoside. J. Food Sci. 32:647-648.

Teynor, T. M., P.D. Ascher, R.D. Widmer, and J.J. Luby. 1989. Inheritance of flower color in Dendranthema grandiflora Tzvelev. (Chrysanthemum morifolium Ramat.) using cultivars in inbreds. I. Plastid pigmentation. Euphytica 42:199-207. 